$J J M L L$

\title{
A Sociopragmatic Study of Intra-Gender Compliment Responses by Saudi College Students
}

\author{
Fathi Migdadi* \\ Department of English, Jordan University of Science and Technology, Jordan
}

Received on: 15-3-2020

Accepted on: 30-6-2020

\begin{abstract}
This study examines compliment responses in Hejazi Arabic as used by Saudi college students. It focuses on the types of compliment responses used, the relationship of the speaker's gender with his/her compliment behavior, and the sociocultural values attached to this behavior. Examples of compliment responses were elicited from King Abdulaziz University students using a number of compliment formulas that are generally considered to be very common in Hejazi Arabic. The compliment responses were analyzed in terms of their semantic, pragmatic, and sociolinguistic characteristics, based on Leech's (1983) politeness maxims and the face-management approach of Brown and Levinson (1987). The analysis shows that the speakers, especially women, accept the compliment paid to them in the majority of the compliment responses collected, which can be accounted for by Leech's Approbation, Tact and Agreement Maxims in which the interlocutors emphasize their closeness with each other. In accordance with face-politeness, the dominance of the acceptance compliment responses makes them as positive politeness strategies in which the compliment recipient negotiates or offers solidarity with the complimenter. In examining the concepts of complimenting in culture-specific contexts, this research provides further data to understand, illustrate and test the abovementioned politeness models. It also contributes to sociolinguistic theory by examining variation in the use of compliment responses in samesex interactions.
\end{abstract}

Keywords: Compliments; Compliment Responses; Gender; Hejazi Arabic; Politeness Maxims, Positive Politeness.

\section{Introduction}

Compliments and compliment responses have been focused on in sociolinguistic research for the benefits they offer in different communicative settings. Compliments serve as a "social lubricant" that enhances social interactions and establishes solidarity between the speaker and the addressee (Wolfson 1983, 89). Furthermore, compliments "reveal the values which are positively regarded within some particular society", and compliment responses (henceforth, CRs) may "provide interesting information on sociocultural values and organization” (Herbert 1997, 497).

\footnotetext{
๑ 2021 JJMLL Publishers/Yarmouk University. All Rights Reserved,

${ }^{*}$ Doi: https://doi.org/10.47012/jjmll.13.1.9

* Corresponding author: fhmigdadi@just.edu.jo
} 
Perhaps the most cited definition of compliments is provided by Holmes $(1988,485)$ :

A compliment is a speech act which explicitly or implicitly attributes credit to someone other than the speaker, usually the person addressed, for some good (possession, characteristic, skill, etc.) which is positively valued by the speaker.

There are two characteristics of compliments: (1) expressing admiration of positive qualities, and (2) focusing on a possession, skill, or personal trait of the hearer. In addition, compliments are generally regarded as positively affective speech acts with multiple functions. Herbert (1989) and Holmes (1988) consider compliments as solidarity offers in which the complimenter attempts to establish or maintain friendship with the complimentee. Compliments are also employed to mitigate negatively affective speech acts like criticisms (Wolfson 1983, 89; Migdadi 2003, 75) and disagreements, to open conversations, and to replace greetings, thanking, encouraging and apologies.

A compliment is the first-pair part of an "adjacency pair" (Pomerantz 1978), the second part of which is a CR. According to Pomerantz (1978), when the complimentee responds to a compliment, he/she does that under two conversational constraints: agree with and/or accept the compliment on the one hand, and avoid self-praise on the other. These restrictions, however, create a communicative dilemma for the complimentee, who has to choose between agreeing with the compliment as the expected next turn for polite interaction and avoiding being involved in self-praise behavior. Pomerantz concluded that American complimentees try to avoid this predicament by striking a balance between explicit acceptance of the compliment and direct avoidance of self-praise. Specifically, she found that the complimentees express their agreement with the compliment but in the process try to scale down or refocus the compliment. Scaling down is achieved through reducing the positive affect of the praise in the compliment given, and refocusing is used when the complimentee shifts the praise to someone other than self.

CRs are considered an illustration of linguistic politeness because they help in maintaining harmonious relations and avoiding communicative breakdowns. Arguably, the most influential theoreticians of politeness are Lakoff (1973a, b), Brown and Levinson (1987), Leech (1983), Ide (1989), Fraser (1990) and Hill et al. (1986). As the present study focuses on conversational utterances occurring naturally within specific sociocultural contexts, Leech's (1983) politeness principle which basically operates in conversational exchanges in daily life situations is used to account for the data collected from the Saudi college students. Brown and Levinson's (1987) politeness theory is also used in the present research regarding complimenting behavior in culture-specific situations to provide further data to the controversial question of the universality of this politeness approach (see Veronica-Diana 2012). The study explores if the notion of face can be successfully applied to how Saudi people perceive and respond to verbal praise of their belongings, appearance, inner qualities and so on.

Notwithstanding the criticisms that have been leveled against these two theories (see Eelen 2001 and Ruhi 2010, 44 for a summary), their use in the current study of CRs stems mainly from CRs being both a verbal behavior that seeks to maintain harmonious relations (Leech 1983) and one that enables 


\section{A Sociopragmatic Study of Intra-Gender Compliment Responses by}

Saudi College Students

interactants to negotiate, enhance and maintain face (Brown and Levinson 1987). This is based on the researcher's desire to avoid the discrepancies revealed in the literature between the two theoretical approaches and disagreement on the choice of one theoretical stance over the other (Ruhi 2010; Baba

1996; Henderson 1996). As pointed out by Ruhi (2010), the maxim approach was found to provide a more comprehensive explanatory framework than Brown and Levinson (1987) for investigating cultural divergences in the context of American English and Chinese CRs (R. Chen 1993), while the same approach was found to be incapable of incorporating cultural constraints in the analysis (Baba 1996). Therefore, to neutralize these theoretical discrepancies, the researcher has analyzed the data using the two theories combined (cf. R. Chen 1993; Ruhi 2010).

In the conversational maxim approach, Leech $(1983,132-133)$ suggests that the language used in different speech events ties to six politeness maxims: Tact, Generosity, Approbation, Modesty, Agreement and Sympathy, with each having a submaxim as follows:

\section{TACT MAXIM}

(a) Minimize cost to other [(b) Maximize benefit to other]

\section{GENEROSITY MAXIM}

(a) Minimize benefit to self [(b) Maximize cost to self]

\section{APPROBATION MAXIM}

(a) Minimize dispraise of other [(b) Maximize praise of other]

\section{MODESTY MAXIM}

(a) Minimize praise of self [(b) Maximize dispraise of self]

\section{AGREEMENT MAXIM}

(a) Minimize disagreement between self and other [(b) Maximize agreement between self and other]

\section{SYMPATHY MAXIM}

(a) Minimize antipathy between self and other [(b) Maximize sympathy between self and other]

In responding to compliments, the Agreement and Modesty Maxims are a source of conflict because if the complimentee, seeking to avoid self-praise, rejects the compliment, he/she is likely to be in disagreement with the complimenter, which violates the Agreement Maxim. Alternatively, the complimentee may accept the compliment to minimize disagreement with the complimenter, but at the same time he/she would then be involved in self-praise, infringing on the Modesty Maxim. Leech notes that once two maxims conflict, the more "powerful" maxim takes priority. He also points out that the strength of each maxim varies from culture to culture, resulting in different strategic options of dealing with inharmonious maxims.

Brown and Levinson's (1987) concept of face, which is the self-image that one wants to show to others, provides another construct for analyzing CRs. Brown and Levinson (1987, 67) argue that conversation participants have negative and positive face wants: negative face refers to "the want of every 'competent adult member' that his actions be unimpeded by others" and positive face to "the want of 


\section{Migdadi}

every member that his wants be desirable to at least some others". During interactions, face-threatening acts (FTAs) are inevitable depending on the nature of the conversation (Brown and Levinson 1987, 65). The addressee's negative face is threatened by impeding actions such as orders and requests, and other actions disregarding the addressee such as disagreements and criticisms cause threat to his/her positive face. However, these negatively affective expressions are contrasted with cases of negative politeness in which the interlocutors avoid imposing on others, and of positive politeness emphasizing solidarity with the addressee (Holmes 1995, 5). In Western culture, accepting compliments indicates the complimentee's attention to the complimenter's positive face wants because the former fulfills the latter's desire of being liked and approved (Brown and Levinson 1987, 70). However, face theory cannot account for the returning or deflecting of compliments by English speakers (Herbert 1989; Holmes 1988; Wolfson 1983) or the frequent use of compliment rejection in some cultures, as done by Mandarin Chinese speakers on Mainland China (Gu 1990; R. Chen 1993).

From a theoretical point of view, the current study aims to re-establish that classic theories of politeness can still be employed as a powerful analytical tool of linguistic politeness. While the recent trend in politeness research seems to be moving away from classical theories such as Leech (1982) and Brown and Levinson (1987) in favor of what is presented as more "progressive" discursive theories and approaches (cf. Spencer-Oatey 2000; Watts 2003; The Linguistic Politeness Research Group 2011), this study lends support to these classical theories. Given the formulaic structure of the expressions used in the Saudi CRs in the dataset, the researcher believes that the exchanges investigated in this study are better examined and described through the prism of classical politeness theory. It is also believed that discursive approaches to politeness would fall short of capturing the systematic patterns of linguistic behavior that are investigated in this paper. Furthermore, as argued by R. Chen et al. (2013), the value of the discursive approach to the study of language use cannot be disputed, but it should not be seen as the only approach to politeness, despite its considerable currency in the literature. As R. Chen et al. $(2013,144)$ put it, "we do not subscribe to the view that a difference in a norm between two cultures necessarily leads to the difference in politeness between them." The Saudi society from which the data are taken is characterized by collectivism rather than individualism, a contrast that is not addressed in Brown and Levinson's (1987) conceptualization of politeness, but as R. Chen et al. $(2013,144)$ argue, the issue of whether Brown and Levinson's theory applies to non-Western cultures due to its alleged Eurocentric bias cannot be resolved by merely stating that there are cultures in which individualism is not the predominant force governing social interaction. Rather, evidence needs to be provided that individualism (and its accompanying notions such [as] autonomy) does not play a part at all in these cultures. (original emphasis)

As R. Chen et al. (2013, 145) further point out, "very few scholars seem to have demonstrated the complete absence of autonomy in a given culture, and probably rightly so, as it would be difficult to imagine a culture whereby the individual is totally submerged in the collective." These theoretical considerations underlie my study of Saudi Arabic CRs in the present study. 
A Sociopragmatic Study of Intra-Gender Compliment Responses by Saudi College Students

\section{Research on CRs}

CRs have been a major area of investigation in pragmatics. Early research on this area began with Pomerantz (1978) and continued with the works of Herbert (1986, 1990), Manes (1983), Pomerantz (1984), Wolfson (1983), Herbert (1989) and Holmes (1988).

These early studies focused on English CRs in different contexts, dealing with objects of compliments, interlocutors involved in complimenting, the syntactic structures used for compliments and CRs, and the CR strategies adopted in English-speaking communities (R. Chen and Yang 2010). The primary research has also categorized CRs into three major types, with each subdividing into smaller strategies (See Pomerantz 1978; Herbert \& Straight 1989; Nelson et al. 1996):

1. Acceptance

Appreciation Token (-Thanks/Thank you)

Agreement by means of a comment (-Yeah, I like it, too)

Upgrading the praise (-Yeah, I can play football well too)

2. Mitigation/Deflection

Account about history (-I bought it from Ohio)

Shifting the credit (-My girlfriend gave it to me)

Question (-Do you really like it?)

Returning (-You look nice, too)

Downgrading (-It's really quite old)

3. Rejection

Disagreeing (A: -You look good and healthy. B: I feel fat.)

4. No Response

5. Request Interpretation

However, more attention started to be devoted to other languages and cultures from the 1990s onward. Studies on CRs in that period investigated, in addition to English, other European languages, notably Polish, German, French, Spanish, and Greek, the Asian languages Chinese, Japanese, Korean and Thai, and the Middle Eastern languages Turkish, Persian and Arabic (see R. Chen 2010, for a crosscultural survey of compliment and CR research in these languages). As noted by R. Chen (2010), considerable and rich diversity can be seen in the way speakers of different languages compliment and respond to compliments. In some cultures, rejection of compliments is often preferred as it involves selfpraise avoidance. Thus, a compliment on one's appearance may elicit responses like No, I look like an old woman (in Korean, Han 1992, 24), No, I don't [look great]. Don't make fun at me; I know I'm just plainlooking (in Chinese, Yu 2008, 42; also see Chen 1993). Speakers of some other languages, in contrast, prefer to accept the praise in ways that seems not to be typical in English (Golato 2002, 2005; Huth 2006; 


\section{Migdadi}

Kasper 2007). The present study aims to add to this variation by investigating CRs in an underexplored language, Saudi Arabic, from a sociopragmatic perspective.

Given the limited number of studies on CRs in Arabic (Nelson et al. 1996; Farghal and AlKhatib 2001; Farghal and Haggan 2006), it is difficult to determine the strategies of responding to compliments, the pragmatics of CRs and how these speech acts interact with different contextual and social factors in Hejazi Arabic interactions. By examining a considerable corpus of CRs used by Hejazi Arabic ${ }^{1}$-speaking university students, the present study aims to identify the most common patterns of responding to compliments and how the socio-cultural norms in Saudi Arabian society are involved in people's complimenting behavior. It also compensates for the paucity of speech-act related research in Arabic, especially in Saudi Arabia, where co-education is prohibited and inter-gender interaction, at least in public, is considered a taboo. In line with politeness researchers (e.g., Okamoto 2002, 102; LorenzoDus and Bou-Franch 2003), the current study focuses on the complementing behavior of Hejazi Arabic speakers in intra-gender interactions to determine if the linguistic patterns that are conventionally ascribed to either male or female style are equally used by both groups.

\section{Methodology}

To examine CRs in Hejazi Arabic, a total number of 291 CRs were collected by twelve senior college students, six males and six females, at King Abdulaziz University (KAU), Saudi Arabia, in the academic year 2013/2014. The fieldworkers were instructed to elicit CRs from their colleagues and friends using various compliment formulas as stimulating expressions, depending on the conversational setting in which they were involved. When KAU students responded to the fieldworkers' compliments, they did that spontaneously without being aware that their complimenting behavior was being observed.

The fieldworkers were also trained to choose their eliciting compliments within topics including appearance, possessions, skills and personality, these being the most frequent features of compliments in many cultures (see Manes and Wolfson 1981and Manes 1983 for American English; Holmes 1988 for New Zealand English; Lewandowska-Tomaszczyk 1989 for Polish). The CRs were collected on the KAU campus in same-sex interactions in a variety of settings, such as friends' gatherings, cafeterias, corridors and classrooms.

To increase inter-rater reliability, the fieldworkers were trained to collect data in almost the same way. For cultural reasons, the researcher could not directly train the female Saudi fieldworkers to collect data, assigning this task to his wife, who worked as an English instructor on the women's campus. Therefore, the researcher trained the male fieldworkers and his wife to elicit CRs from other students by explaining the topic of the study, defining compliments and CRs, and introducing types, topics and functions of compliments and CRs. He also used some role-playing scenarios to ensure that the trainees could observe and document CRs in worksheets correctly. In turn, the researcher's wife coached the six female fieldworkers to collect CRs on the women's campus in the same way.

Like other data collection methods, the elicitation technique used in this study has its own strengths and weaknesses. The study is based on an adequate variety of compliment responses because the 


\section{A Sociopragmatic Study of Intra-Gender Compliment Responses by Saudi College Students}

compliment formulas used to elicit CRs covered all the topics in which CRs were likely to occur. The elicitation method was also efficient as the fieldworkers collected many CRs easily in a limited period of time (Turnbull 2001). Since the fieldworkers acted as the complimenters and could decide which features to compliment on, they often participated in interactions where they could give appropriate compliments to elicit the CRs needed to complete their data. However, elicitation techniques used in pragmatic research are often criticized for producing less naturalistic data, as the researcher may interfere in the frequency and nature of interactions to obtain the language forms needed for his/her study. This problem has to a large extent been avoided in this study because the focus is on CRs which have been produced naturally by KAU students. Another disadvantage of the elicitation technique used in this study is that the phenomenon of responding to compliments is not captured with relatively high frequencies and in comparable situations. The data, however, have revealed important generalizations about intra-gender complimenting behavior of Hejazi Arabic speakers at KAU.

\section{Analysis}

The data in the present study have been analyzed qualitatively and quantitatively, based on earlier studies of CRs. In the qualitative part, two Saudi-Arabic native speakers working as research assistants were trained to code the data according to a coding scheme derived from these studies. A continuing process of discussion, conceptualizing, comparing, categorizing and revision was carried out to determine how the data fit in different CR types, until the coders reached an appropriate coding scheme. To test inter-coder reliability, the data were coded by the two coders independently. The correlation coefficient of the coding operation was consistent with a percentage equal to $0.90 \%$, a level that is typically accepted for human coding. In the quantitative analysis, the CR strategies were tabulated and their frequencies were calculated.

\section{CR types}

Table (1) below clearly shows that KAU students employed compliment acceptance much more frequently, at $68.7 \%$, than evasion and rejection, at only $16.1 \%$ and $15.1 \%$, respectively. Comparatively speaking, the higher percentage of acceptance responses supports Syrian data in Nelson et al. (1996) at $67 \%$ versus $33 \%$ non-acceptance, Jordanian CRs in Farghal and Al-Khatib (2001) at 83.85\% versus $16.15 \%$ and Egyptian data in Morsy (1992) at $72 \%$ versus $28 \%$. The percentages of acceptance in native English CRs are also higher than those of other response types, although the difference is not as obvious as that for Arabs. For Americans, compliments accepted amount to 58\% in R. Chen's (1993) study and $50 \%$ in Nelson et al.'s (1996) study. Holmes (1988) found 61\% of acceptance tokens for New Zealanders, and $43 \%$ for South Africans was reported by Herbert (1989).

It can be understood from this that the conversational behavior of KAU students, as is the case with Arab and Western speech communities in general, is clearly governed by Brown and Levinson's (1987) politeness principles of "seek agreement" and "avoid disagreement" and by Leech's (1983) Tact and Agreement Maxims. Thus, all responses rated as acceptance, except for upgrading (as will be explained 


\section{Migdadi}

below), avoid disagreement with the complimenter, fitting in with Brown and Levinson's category of positive politeness strategies which make the hearers feel good about themselves. These strategies can also be captured by Leech's politeness principle, because they explicitly or implicitly follow the Agreement Maxim. One culture-specific explanation of the predominance of acceptance in the Saudi students' responses to compliments is related to Arab-Islamic norms of communication in Saudi Arabia in which people are encouraged to respond to greetings with better ones. In the subsequent sections, CR strategies used in the study is defined, exemplified and discussed in terms of their frequencies and relevance to politeness theories and different socio-cultural norms.

Table 1: Distribution of CR Types in Hejazi Arabic

\begin{tabular}{lccc}
\hline CR Category & Male-to Male Freq.(\%) & Females-to-Females Freq. (\%) & Total Freq. (\%) \\
\hline I. Acceptance & $109(64.1)$ & $91(75.2)$ & $200(68.7)$ \\
1. Returning Compliment & $40(36.7)$ & $33(36.3)$ & $73(36.5)$ \\
2. Blessing & $28(23)$ & $14(15.4)$ & $42(21)$ \\
3. Thanking & $12(11)$ & $16(17.6)$ & $28(14)$ \\
4. Confirmation & $7(6.5)$ & $13(14.3)$ & $20(10)$ \\
5. Ostensible Offering & $11(10)$ & $1(1.1)$ & $12(6)$ \\
6. Upgrading & $2(1.9)$ & $8(8.8)$ & $10(5)$ \\
7. Satisfaction & $5(4.6)$ & $3(3.3)$ & $8(4)$ \\
8. Request Information & $4(3.7)$ & $3(3.3)$ & $7(3.5)$ \\
\hline II. Evasion & $32(18.8)$ & $21(11.7)$ & $53(17.8)$ \\
1. Joking & $16(50)$ & $4(19.1)$ & $20(37.7)$ \\
2. Account & $9(28.1)$ & $7(33.3)$ & $16(30.1)$ \\
3. Question & $3(9.4)$ & $7(33.3)$ & $10(18.8)$ \\
4. Transfer & $4(12.5)$ & $3(14.2)$ & $7(13.2)$ \\
\hline III. Rejection & $29(17.1)$ & $9(7.4)$ & $38(13)$ \\
1. Envy Interpretation & $13(44.8)$ & $2(22.2)$ & $15(39.5)$ \\
2. Downgrading & $7(24.1)$ & $3(33.3)$ & $10(26.3)$ \\
3. Disagreement & $4(13.7)$ & $2(22.2)$ & $6(15.8)$ \\
4. Request Interpretation & $4(13.7)$ & $1(11.1)$ & $5(13.2)$ \\
5. No Acknowledgement & $1(3.4)$ & $1(11.1)$ & $2(5.3)$ \\
\hline Total & $170(100)$ & $121(100)$ & $291(100)$ \\
\hline
\end{tabular}

\subsection{Acceptance}

This strategy is used when the complimentee accepts the compliment paid to him/her. The following are sub-categories of acceptance:

\subsubsection{Returning compliment}

The complimentee returns a compliment to the addressee (e.g., inti ahla 'You are prettier' and cyūnak elhilwa 'It is your eyes that are beautiful', lsānak elhilu 'It is your speech that is nice', elhala yiḥla $b h a l a \bar{k}$ 'Beauty increases with your presence', and $h \bar{a} \underline{d} a$ min $\underline{d} \overline{o g a k}$ 'This (i.e. compliment) comes from your (good) taste', hād a min țīb aṣlak 'This (compliment) comes from your good lineage', tistāhal aktar 'You deserve more (than what I have)'. The compliments returned seem to have different functions in the Saudi context. As explained by R. Chen (1993, 58), when the complimentee returns the compliment, he/she actually pays back the debt to the complimenter. This way, a compliment can cause threat to the complimentee's negative face, because it forces him/her to express admiration of the complimenter. However, returned compliments may also be motivated by the Approbation Maxim in accordance with 
A Sociopragmatic Study of Intra-Gender Compliment Responses by Saudi College Students

Leech's (1983, 132) Politeness Principle, as the complimentee who returns the compliment to the complimenter increases praise to the latter. Returned compliments are also positive politeness strategies according to Brown and Levinson's (1987) face theory, because they are designed to make the hearers feel good about their positions and interests.

Returning compliment has the highest number of occurrences (36.55\%) within the acceptance superstrategy, and this is attributed to two basic reasons. First, it is consistent with an Islamic principle that a Muslim has to return a greeting with an equal or one (see Quran 3, 86). Second, as returned compliments are usually formulaic and draw on a limited set of vocabulary items and structures, they lend themselves easily to recall on the part of complimentees, who use them frequently in different situations.

When returning compliment is viewed in the wider context of complimenting across cultures, the predominance of this sub-strategy in the present corpus contrasts with both Herbert's $(1986,80)$ findings about American English and Holmes's $(1988,496)$ results for New Zealand English, which showed that returning compliments is used in very low percentages by people who accept compliments in these cultures. However, it is consistent with R. Chen's (1993) findings about the complimenting behavior of speakers of American English, where returned compliments have the second highest number of occurrences in his data. It is also in line with Farghal and Al-Khatib's (2001) results for Jordanian college students, in which returning compliment ranked second after thanking within the macro-strategy of acceptance, at a percentage of $35.52 \%$.

\subsubsection{Blessing}

The complimentee wishes for the complimenter to be blessed (e.g., jazāk allah hêer 'May God reward you', bārak allah fìk 'May God bless you', tislam/yislamu 'May you be well', 'ugbālak, enšāllah 'May you be next, God willing', bilcäfyah 'May (this food) give you health'). This strategy is related to religious fatalism in Arab Muslim culture (e.g., Farghal 1993; De Atkine 2004), which means that humans do not have control over all events and that many things are determined by God, or Fate (Nydell 1987, 17). As Islamic faith is clearly integrated into the organizational structure of Saudi society, one may understand that the complimentees' praying for God to bless the complimenter with happiness, prosperity and good health is a reflection of the community members' firm belief that it is only God who has the power to grant or withhold happiness, health, wealth and prosperity.

Accounting for $21 \%$, this strategy occupied the second highest position in the category of acceptance CRs, which indicates that positively affective communication in Saudi culture is achieved or enhanced when the realization of such wishes is attributed to the power of God. In Brown and Levinson's theory (1987), blessing fits in with positive politeness strategies as the complimentee attends to the complimenter's interest of achieving success and pleasure and by emphasizing his/her membership within the religious and cultural group. 
Migdadi

\subsubsection{Thanking}

Thanking refers to the expression of appreciation by the complimentee, using words derived from the trilateral root ̌̌-k-r 'thank' (e.g., šukran jazīlan ' Great Thanks ', aškurik 'Thank you', maškūr 'Thank you' (literally: You're thanked)). Thanking was often accompanied by other appreciation and acceptance tokens (e.g., šukran, jazāk allah h̄ēr 'Thanks, may God reward you', maškūr, enšāllah etțalic uxtha 'Thanks. May you be blessed with the same'), which indicates that compliments are so highly valued that a thanking expression is too weak to express the complimentee's feeling of appreciation. This strategy conforms to politeness principles in both theories of politeness suggested by Leech (1983) and Brown and Levinson (1987). It follows Leech's Tact Maxim as it maximizes benefit to other (i.e., complimenter) and Brown and Levinson's negative politeness insofar as the complimentee emphasizes deference to the complimenter. Ranking third in the category of acceptance CRs, appreciation is less preferred by Saudi

students than with speakers of other languages, who tend to resort to it more than to certain types of CRs (cf. R. Chen 1993; Holmes 1988; Herbert and Straight 1989).

\subsubsection{Confirmation}

This strategy, which ranked fourth in the strategies of acceptance, involves using utterances that reaffirm the positive affect of the compliment (e.g., akìd țayib cašān el-wāldeh cimlatu 'It is surely delicious because my mother made it', akìd hilu 'Definitely nice', hādi sayyārah țāl cumrak 'This is REALLY a car, may God prolong your life ', aḥsan mā gelt 'The best of what you've said', nās ticref tištari 'Some people know how to buy', toyota sayyārah sayyārah 'Toyota is THE car', hādi elmudākare eljayyida 'This is a really good study'). Confirmations may also integrate elements of the original compliment into the response. For example, a male student responded to the compliment ěš hal-marsìdis elhilwa 'What a nice Mercedes!' by saying hāda ilmudēl marrah hilu 'This model is very nice'. The compliment ěš eljawwāl el-hilu 'What a nice cellphone!', which was paid to a female student, was incorporated in her response awwal mā šuftuh marrah cajabni 'The moment I saw it (the cellphone) I really liked it.' Confirmation is considered as a case of agreement because the complimenter and complimentee are in accord and the compliment force is not challenged by the latter. The avoidance of disagreement and emphasizing of agreement in this strategy relate it to both Leech's (1983) Agreement Maxim and Brown and Levinson's (1987) positive politeness strategies.

\subsubsection{Ostensible offering}

This strategy, which came fifth at $6 \%$, involves gesturally offering the object being complimented to the complimenter (e.g., mgaddam 'I'm offering it to you (as a gift)', yifdāk el-jawal 'My mobile is all yours', mā yistāhaluh a'azz minnak 'No one would deserve it more than you'). Ostensible offering is only one example of a large category of ostensible speech acts (e.g., ostensible invitations, ostensible apologies, ostensible compliments and others). As is the case with ostensible invitations in Arabic (see Abdel Hady (2013) for Jordanian Arabic, and Radcliff-Johnson and El-Hilawi (2016) for Iraqi Arabic), this strategy looks like a genuine act of offering, as both the offerer and the receiver pretend the 


\section{A Sociopragmatic Study of Intra-Gender Compliment Responses by Saudi College Students}

presenting is sincere and act accordingly. As the data show, the offerer, understandably, does not repeat, insist on or intensify the offering and the receiver always expresses gratitude and politely declines, which indicates that ostensible offering is only a 'lip-service' strategy used to show gratitude, sociability and generosity. Therefore, like other CR strategies, ostensible offering is a phatic communion strategy in which the offerer attempts to strengthen his/her social relations with the addressee, fitting in with Brown and Levinson's (1987) positive politeness strategy of making the hearers feel good about themselves. It also conforms to Leech's $(1983,132)$ Tact Maxim as it is a case of verbally maximizing benefit to others.

\subsubsection{Upgrading}

Another acceptance strategy, which came in sixth place, is upgrading, whereby the force of the compliment is intensified or, as Wierzbicka $(1991,138)$ puts it, what is "good" is replaced by "very good”. Responding to the compliment ēš eššațāra de 'How smart of you!' one of the female students said elhamdulillah dāyman šătrah 'Thank Allah, I am always smart', increasing by that response the power of the praise (but still portraying he intelligence as a gift from God, for which she shows gratitude through saying elhamdulillah; see above). The compliment elhala de tayyib 'This dessert is delicious', which was given by a female student to her female colleague, was upgraded as marrah tayib 'very delicious' by the recipient.

Upgraded CRs violate the Modesty Maxim by implying that the complimentary force is understated as well as the Agreement Maxim, as the complimentee disagrees with the complimenter on the strength of the compliment, hinting that it is weaker than warranted. However, as pointed out by Ruhi (2006), since the upgrades in the present study occur among young friends, they may fall under the phenomenon of banter, which is described by Leech $(1983,144)$ as a form of mock-impoliteness in which offensive language is taken by the hearer to be polite. Therefore, this strategy is likely to communicate politeness rather than impoliteness and can increase emotional closeness between the parties of the compliment event.

In Brown and Levinson's politeness theory (1987), the function of disagreement achieved by upgrades causes them to be bald-on record politeness strategies, in which the complimentee does not attempt to alleviate the threat to the complimenter's face. Still, the negative affect associated with these responses is less relevant for this study in light of the fact that they occur in a small percentage (5\%) among friends who are normally expected to give and receive mockingly impolite utterances in this type of communication. This strategy seems to emphasize camaraderie and familiarity between the interlocutors rather than disrupt their interpersonal relations.

\subsubsection{Satisfaction}

Satisfaction was used relatively infrequently (4\%). In this strategy, the complimentee expresses satisfaction about the compliment, as in alhamdulillāh 'Thank God', man jadda wajad 'Working hard pays off', and yā rabbi laka lhamd 'O, my Lord, all praise be to you', ah̄īran šarētha 'I've finally bought it (the car)'. Satisfaction seems to follow two of Leech's (1983) Maxims: Agreement and Sympathy. 


\section{Migdadi}

Thus, the complimentees selecting this strategy did not show any signs of discomfort or disagreement in accordance with the first Maxim, and the other Maxim is observed as well, as understanding between the interlocutors is increased in this strategy.

\subsubsection{Requesting Information}

This is the least used (3.5\%) strategy of acceptance, and it occurs when the complimentee asks the complimenter to provide more information about the praise (e.g., kêf bas 'How do you like it?' billahi kēf min jaddak 'By God, seriously, how do you like it?', billah māni hilwah 'By God, am I not really pretty?'). This strategy indicates that the complimentee approves of the praise and looks forward to hearing more about it, and so it is a positive politeness strategy (Brown and Levinson 1987) that serves to establish harmony between the complimenter and complimentee.

\subsection{Evasion}

In a number of complimenting contexts, the complimentee avoids accepting or rejecting the compliment explicitly, although he/she acknowledges its occurrence. Many of the evasion responses in this study, especially joking, serve as positive politeness strategies, which actually makes them closer to acceptance than rejection.

\subsubsection{Joking}

Jokes are humorous utterances which make fun of the compliment, and they account for the highest percentage $(37.7 \%)$ of evasion CRs. They occur in higher percentages in this study than in previous CR studies (e.g., R. Chen 1993; Ruhi 2006). Although humorous activities such as teasing, sarcasm and 'making fun of someone' can be perceived as 'impolite' and 'unpleasant' (Kotthoff 1996, 317), the same speech acts are often used in this study as means of enhancing camaraderie between the complimentee and the complimenter. This is consistent with Brown and Levinson's (1987) view, also expressed by others (Norrick 1993; Tannen 1993), which considers joking in conversation as a potentially friendly and sociable action. Brown and Levinson $(1987,124)$ point out that "joking is a basic positive politeness technique", i.e. the speaker may use a joke in responding to a faux pas of the hearer to put him/her "at ease", and that humorous interaction helps to enhance shared knowledge between the speaker and the hearer. Similarly, Tannen (1993) argues that joking may indicate a difference of power in some contexts, but it can also reveal equality and solidarity in other contexts. In those cases, joking is important in confirming intimacy between the two conversational parties.

There are many instances in the data in which joking is used by the complimentee to attend to the complimenter's positive face wants and maintain friendship with them. For example, some students responded to the compliment ēš eššațāra de 'How smart!' by choosing expressions of irony such as ma šuft šay lalhīn 'You haven't seen anything (of my intelligence) yet!', dāfūr, șaḥ? 'Genius, right?', lisa da wa la šay 'This is not all (of my intelligence)!' and min zamān wana šațer 'I've always been smart!'. In these examples, the speakers do not mean what they say, but they cheerfully joke about the praise, perhaps to encourage the addressee to get more involved in the compliment event. 
A Sociopragmatic Study of Intra-Gender Compliment Responses by Saudi College Students

In other situations, the complimentee's sense of humor is displayed through jokingly disagreeing with the compliment. A student responded to a compliment about his handwriting by saying battil mujāmalah, li'n hadḍi ta9bān 'Stop complimenting me because I my handwriting is lousy!' and the compliment ēš eššațāra de 'How smart!' made by a male student to another one was met by the joke $\dot{g} u \check{s}$, hallak sākit '(It is by) cheating! Keep silent!'. The pragmatic function of these disagreements is to create a humorous atmosphere that helps to maintain the friendship between the interlocutors. Other examples of humorous CRs are adri min gèrmātgūl 'I know (that I am handsome) without you telling me so!', ēš šāyifni mā albas walla kēf 'Do you mean I am usually not well-dressed? What do you mean?', ana kulli cala bac di hilu 'I am entirely handsome', wēš ticrif int fi-l-mōzah 'What do you know about fashion?!' and ukul winta sākit 'Eat and keep silent!'.

As is the case with acceptance CRs, the students' use of many joking CRs reflects their comfort with being complimented, and their humorous deflections of the praise are more likely to please the complimenters than embarrass them. So this type of CR fits in with Brown and Levinson's (1987) category of positive politeness strategies functioning to increase social bonding between the interlocutors. In the Maxim approach, although jokes violate the Agreement Maxim through implying disagreement between the complimenter and the complimentee, they basically function in the data as banter in a way similar to upgrades. Thus, the complimentee who uses jokes to respond to a compliment avoids confirming the praise or rejecting it, but such apparent impoliteness is taken to be a display of kindness that has a positive effect on the relationship between the interlocutors.

\subsubsection{Accounts}

Used in $30.1 \%$ of the evasion CRs, this strategy ranks second after joking. Accounts provide evasive comments about different aspects of the item complimented (e.g., wallah šārē min Jeddah 'Well, I bought it from Jeddah', lāzim tg்ayyer cala gōlithum littikēt 'We need to change the etiquette, as people say it", halās ajīblak ilmarrah iljāyih 'OK, I'll get you some next time'). Although such comments are built on the contents of the compliments, they do not directly accept or reject the compliment given. In social interaction, the complimentee's commenting on one's compliment reflects his/her interest in what is said, which is likely to maintain good relations between the conversation participants. Therefore, accounts can

be considered as statements of solidarity, which illustrates Brown and Levinson' (1987) positive politeness strategies and Leech's (1983) Sympathy Maxim, in which opposition between self and other is minimized.

\subsubsection{Questions}

As in accounts above, the complimentee in this strategy avoids explicit acceptance or rejection of the compliment by trying to extract more information about the aspect being complimented (e.g., ěšfih hilu? 'What's particularly nice about it [the mobile]?', elhin bas 'araft? 'You knew about it (my purchase of a new car) only now?!'). By seeking out more information from the complimenter, this strategy is very 


\section{Migdadi}

likely to enhance friendship between the interlocutors, fitting in with the positive politeness strategies of Brown and Levinson (1987).

\subsubsection{Transfer}

This strategy is the least common (13.2\%) within the category of evasion and contains utterances which reassign the target of the praise to a third party (e.g., allah yihalli elwāldah. hāda el-hala min yaddha 'May God bless my mother; this dessert was made by her', wallah abūya yacțe l-cāfyah 'May God give my father good health (for buying me the car)', ettawfig min Allah 'Guidance (in study) is from Allah'). Such CRs imply that the addressee is not the person to whom the credit should be directed, which makes their classification as an evasion strategy more plausible that considering them as acceptance or rejection utterances. Its use indicates the speakers' attempts to be honest in their responses, which is consistent with Arab-Islamic values emphasizing truthfulness.

\subsection{Rejection}

In a number of situations, the students have rejected the compliments paid to them in different ways. However such rejection does not necessarily threaten the face of the complimenter as shown in the following strategies:

\subsubsection{Envy interpretation}

Among the students who rejected compliments, this strategy was used most often and constituted $39.5 \%$ of the examples. Envy is related to the concept of the 'evil eye' in Arab culture. Migdadi et al. (2010) point out that many Arabs think that complimenting someone on a socially desirable aspect, such as appearance, offspring, wealth, or property, is likely to bring about the evil eye and thus inflict harm. Thus, as in Jordanian Arabic (Migdadi et al. 2010), the complimentee may ask the complimenter directly to recite different religious supplications in response (e.g., gūl mā̌šallah 'Say 'May the grace of God be upon it' (e.g. the car)', ud $\underline{d k u r}$ allah 'Mention the name of God', utkur āllah wil9èn mätšāwer 'Mention

God to avert the evil eye'), or the complimentee him/herself may recite a prayer (e.g., yacțini hierha uyikfini šarrha 'May God bestow on me its good and protect me from its evil', allah yikatter 'May God increase (the blessing)') to prevent the evil eye from causing harm to the complimentee or his/her possessions. Here the complimentee's use of Blessing as a shield against the evil eye seems to be done for the complimentee's own sake and does not seem to have much to do with the complimenter, which can be regarded as a case of politeness oriented to one's own interest. This is closely related to R. Chen's (2001) notion of 'self-politeness', which refers to "cases in communication where the need to protect and enhance one's own face influences what one says and the way she says it" and where 'self' "does not only refer to the speaker herself, but also those aligned with the speaker: her family, friends, colleagues, clients, and even her profession" $(2001,88)$, and, in our case, valuable things associated with the speaker (i.e. the complimentee). Within this notion of self-politeness, the complimentee's request for the complimenter to invoke particular religious protective formulas clearly becomes, following R. Chen 


\section{A Sociopragmatic Study of Intra-Gender Compliment Responses by Saudi College Students}

(2001, 88), a kind of "self-defense mechanism" against what is perceived by the complimentee as a potential face threat.

Although one may look at this type of response as a sign of unmitigated rejection of the praise given, it can be considered, based on the Saudi data, as a bald-on record politeness strategy where no attempt is made to minimize the threat to the complimenter's positive face. This is so for two reasons. First, such unmitigated rejections are employed in situations where the interlocutors are friends and less likely to be shocked or embarrassed by each other's direct or even impolite language (Brown and Levinson 1987). In addition, they are related to Islam, as the complimenters are reminded to mention the name of Allah to neutralize the evil eye perceived to accompany a compliment (see Migdadi et al. 2010). Since Saudis generally adhere to Islamic faith, they are expected to look at the direct reminders to invoke Allah as religious teachings that are valued by the complimentees rather than FTAs which cause discomfort to the complimenters.

\subsubsection{Downgrading}

The complimentee may reduce the force of the compliment. When a male fieldworker paid the compliment ēš eššațāra de 'How smart!' to another male student, the latter downgraded the compliment by saying yāšēh kulu bilg̀uš mašši ḥālak 'Oh man, it is all by cheating, let it go!'. In another situation, a female student offered home-made desserts to her friends on campus, and one of them complimented her by saying hāda elhala marrah tayib 'This dessert is very delicious'. The CR was agal min elwājib, mgasrin 'It is less than you deserve. It's nothing', which clearly downgrades the complimenter's admiration. Such responses which scale down the level of praise often reflect the complimentee's modesty in agreement with the Arab-Islamic principle whereby modesty is considered as a personal virtue that is valued as a foundation of good morality. Therefore, the complimentees' cultural norms motivate their giving priority to the rejection of compliments over accepting them, which is consistent with Leech's (1983) claim that interlocutors may prefer a maxim to another one for social reasons. Scaling down the compliments in this strategy also agrees with Pomerantz' (1978) findings about the complimenting behavior of Americans.

\subsubsection{Disagreement}

A compliment may be rejected by disagreeing with the content of the complimenting expression. A male student disagreed with his friend's compliment ěš el-jawwāl el-hilu de 'How beautiful this mobile is!' by saying bass hajmuh kabīr, abgāali I-phone 'But it is too big. I want an iPhone'. The compliment abg்a akūn nahîfah kida, mitl $A$ 'I would like to be as slim as A' was met by the disagreement response $m \bar{a}$ abḡăhā, wazni mā yizīd 'I don't want that. I am gaining no more weight'. Such difference of opinion between the complimenter and the complimentee is often expected among Saudi college friends of the same gender and age. It may even function as an act of maintaining or strengthening friendship as it allows for further negotiation of the praise. This strategy illustrates the complimentee's balancing act between agreement with the complimenter and avoiding self-praise (Pomerantz 1978, 80; Leech 1983, 


\section{Migdadi}

136). The complimentee prefers to be modest and disagrees with the complimenter, which is consistent with the Modesty Maxim.

\subsubsection{Request Interpretation}

This strategy is used when the complimentee interprets the compliment as a request to have or borrow the object of the compliment (e.g., la thāawil mā rah tirkab fîha 'Don't try! You won't get in it (the car)', tibga tsüghā 'Do you want to drive it?', actẹek iyyāh withalli 'Shall I give it to you and leave me alone?', šarētuh min sūg eljawwālāt āhludlak mițlu? 'I bought it at the mobiles market. Shall I buy one for you?'). In this strategy, although the CR addresses the compliment directly, it rejects the implication of requesting that emerges from it. Given that such inferred requests impede on the addressee's choice of action, this CR strategy is considered another context in which a compliment may be viewed as an FTA that could cause communicative discomfort.

\subsubsection{No acknowledgement}

The complimentee does not provide a verbal response to the compliment. This strategy is used the least in the rejection data, accounting for only $5.3 \%$ of the CRs in the study.

\section{Gender and CRs}

When CR strategies are examined for gender-based differences, it is found that acceptance differs most significantly between genders, followed by rejection and evasion, respectively. In this section, the men's response behavior to compliments is compared to that of the women within each of these categories. As mentioned earlier, the researcher could not collect any compliment exchanges between men and women for reasons related to cultural constraints. Therefore, the relationships of gender with CRs that are discussed in this study are limited to same-sex interactions (i.e., male-to-male and female-tofemale) which are produced by fieldworkers from the same gender as the compliment receiver.

As far as relationships of gender with compliment acceptance are concerned, the percentage of compliments accepted by women is higher than that of the male group (75.2 vs. 64.1). Given that compliment acceptance is an efficient strategy of positive politeness, this finding fits in with Holmes' (1998) observation that women are more likely to use linguistic devices that stress solidarity than men.

Acceptance is the first CR type in which there are clear gender differences, as shown in Table (1). These mainly concern four sub-strategies of acceptance including blessing, offering, confirmation, and upgrading. Thus, the men used blessing (e.g., rabana yiscidik 'May Allah please you!', Allah yihalīki ya galbi 'May God protect you, dear') significantly more frequently than the women (23\% vs. $15.4 \%)$. This is attributed to the fact that Saudi men, who have more freedom of movement and less household commitments, are usually involved in more religious activities in mosques, clubs, conferences and presentations. In addition, as heads of their families, Saudi men are usually expected to encourage and monitor their families' adherence to different Islamic teachings and rules, and so they have to act as 


\section{A Sociopragmatic Study of Intra-Gender Compliment Responses by Saudi College Students}

models for them by using religious expressions in different communicative events such as complimenting.

Another subcategory of acceptance which is used differently by men and women is ostensible offering (e.g., mgaddam 'I am offering it to you'). As shown in Table (1), 10\% of the men's acceptance CRs is ostensible offerings, but only $1.1 \%$ of the women who accept compliments insincerely offer the object being praised. Although ostensible offering is a lip-service strategy as mentioned earlier, it is arguably related to Saudis' generosity which is often associated with men more than women as the former group, due to their social leadership, initiate and plan charity activities such as donations, dinner invitations, offerings and so on.

Accepting a compliment through confirmation also varies by the complimentee's gender. As can be observed in Table (1), $14.3 \%$ of the female students confirm the compliments they receive from their female colleagues, whereas only $6.5 \%$ of the men use this strategy in their CRs. This finding indicates that Saudi women are often willing to be evaluated positively and they are aware of their praiseworthy attributes. One more acceptance sub-category in which the two genders use CRs differently is upgrading. A higher percentage of women used this strategy by increasing the force of the compliments paid to them.

The female versus male preferences with respect to evasion are evident in two subcategories: joke and questions. As for joke, Table (1) shows that men use jokes in response to compliments significantly more frequently than women (50\% vs. $19.1 \%)$. The reason for this phenomenon has to do with the extent to which the topic of the compliment is important for the complimentee. Thus, male students, who are often not as interested in appearance as women, are likely to make fun of the compliments they receive on a new $\theta o b$ (a traditional ankle-length garment), a new headdress, or on how they have groomed their beards or mustaches. In addition, Saudi men seem to be academically less motivated than women, so their tendency to joke about compliments on good grades and cleverness is something to be expected. Regarding questions, as is shown in Table (1) above, a significantly higher percentage of questions is used by women as compared to men $(33.3 \%$ vs. $9.4 \%)$. Since women's questions are mostly used in response to appearance compliments, we can argue that the use of this strategy is consistent with women's tendency to care about appearance more than men do (Wolfson 1983). Because women are more interested in appearance, they like to ask questions about different aspects of their appearance.

Within the strategy of rejection, the categories of envy interpretation and request information include the highest percentages of gender-linked differences. A higher percentage of men interpret compliments as an envy device as compared to women (44.8\% vs. $22.2 \%)$. Envy perceived to be caused by a positive evaluation of one's possessions triggers a fear of its negative effect on one's expensive assets (e.g., houses, real estate, cars), more so than with inexpensive items (e.g., calculators, watches, mobiles, pens). Since male students received many possession compliments on their cars, many of them conceive of these compliments as triggering the 'evil eye' and think that they should be accompanied by invocations to protect the complimentee from envy. In contrast, the women who received possession compliments on inexpensive items, such as mobiles, pens and handbags, are not afraid of envy in the eye 


\section{Migdadi}

of the beholder, and so they are less likely to take compliments on their inexpensive possessions as expressions of jealousy. Concerning request interpretation, men used this category more frequently than the women, which indicates that men are more expected to exchange items and services than women. So a man is more likely to take a compliment on his belongings as a request made by the complimenter to have or use the complimented item.

One more difference between men and women in responding to compliments is related to lexical choice. Women are found to use more positively affective words than men do and are more likely to intensify their appreciation of compliments. While women used emotional address forms (e.g. habībti 'sweetheart', ya galbi 'my sweetie', ya 'yūni 'dear' (literally 'my eyes'), ya hayāti 'darling' (literally 'my life'), ya ġālyah 'precious', ya 'asal 'honey') twelve times, only two male students used ya ġāli 'precious' and habībi 'dear' in addressing a friend. In addition, when the women appreciate or return compliments, they intensify the praise (e.g., marrah hilwa 'very pretty', ahla 'prettier', marrah ațab 'much tastier') more frequently than the men ( 8 vs. 3). Another difference between the sexes in vocabulary selection is men's use of Standard Arabic expressions and proverbs (e.g., yā rabbi laka lhamd 'Oh, my Lord, all praise be to You', enta ajmal 'You are more handsome', hāta min fạ̣l ellāh 'This is a blessing of God')

in six CRs, while women never used such forms in their CRs. This finding seems to contradict Lakoff's (1973a) observation that women use more standard forms than men do.

Finally, there are several significant, though not statistically, differences between the complimenting behavior of male and female college students in Saudi community. This finding is consistent with the perceived stereotypes concerning gender segregation in Saudi culture, which has seemingly led to a separate communicative competence for each gender.

\section{Conclusion}

The foregoing analysis of CRs as used by Saudi college students has thrown light on the significance of this speech act from a socio-pragmatic point of view. It has shown that CRs play an important role in managing face in communication in Hejazi Arabic. CRs are found to perform a social function, which is to offer or maintain the solidarity implied in the compliment.

CRs have been categorized into three main categories of acceptance, evasion and rejection, based on Holmes's (1988) analysis of CRs in New Zealand English. The analysis has shown that Saudi students favor acceptance (68.7\%) much more than evasion and rejection. Among acceptance responses, returning compliment is used most frequently, followed by thanking, confirmation, ostensible offering, upgrading, satisfaction and request assurance, respectively. Within the super strategy of evasion, joking is shown to be used more frequently than accounts, questions or transfer, in that order. When a compliment is rejected, envy interpretation occurs in most cases, while downgrading, request interpretation and no acknowledgement are used in lower percentages.

Saudi college students' complimenting behavior can be captured by the major politeness theories and manifests elements of Arab-Islamic socio-cultural norms. Their frequent use of acceptance sub-strategies is a sign of their comfort in receiving compliments. This is in line with Brown and Levinson's (1987) 


\section{A Sociopragmatic Study of Intra-Gender Compliment Responses by}

Saudi College Students

politeness theory, where compliments are considered as positively affective speech acts. Such behavior also follows Leech's Approbation, Agreement, Sympathy and Tact Maxims. Even students' evading or rejection of compliments reflects their communicative orientation to politeness, as they do that occasioned by the particular conditions of the discourse.

Arab-Islamic values related to verbal and non-verbal communication also characterize many of the CRs collected in this study. For example, responding to a compliment by returning another compliment can be understood in light of Islamic ethics. Moreover, when the complimentee asks the complimenter to mention the name of Allah, this can be understood within the context of seeking protection from the evil eye, which is a deep-rooted phenomenon in Arab-Islamic societies, like Saudi Arabian society. The offerings and blessings that are frequently used in the data are a reflection of the great extent to which language is systematically influenced by the various social forces in Saudi culture (see Davies 1999: 48).

When the relationship between CRs and the gender of the complimentee is examined, it appears that women are more likely to accept compliments than men (75. 2 vs. 64.1). This finding is in agreement with linguistic studies commonly showing women to be more adherent to polite communication. Women also used more questions than men, but the latter produced more jokes and 'envy interpretations' in responding to their friends' compliments. This difference is revealed to be related to the topics of the compliment. Thus, because women tend to value and focus on appearance more than men do, they responded to compliments within this topic by using questions to obtain more details about the features complimented on. Similarly, male students who are more likely to own valuable possessions (e.g., cars) may consider compliments on these items as a sign of envy, and thus respond by using expressions perceived to protect the complimented object from such 'envy'.

This analysis supports earlier studies conducted by other researchers (e.g., Nelson et al. 1993 Y. Yuan 1998; Farghal and Al-Khatib 2001; L. Yuan 2002; Ruhi 2006; Tran 2006) in other cultures. However, it is important to mention that the findings of this study are limited to complimentary behavior by a highly educated group and should not be generalized. Future research on compliments and CRs in this language variety may explore variables that are not included in the present study, including how linguistic behavior interacts with social factors such as age, religion, and social background. In addition, as suggested by R. Chen (2010) as regards other languages, future research on Arabic compliments and CRs needs to be approached in connection with and in light of studies that were conducted two decades ago to measure any social changes that are often reflected in people's use of these speech acts. 
Migdadi

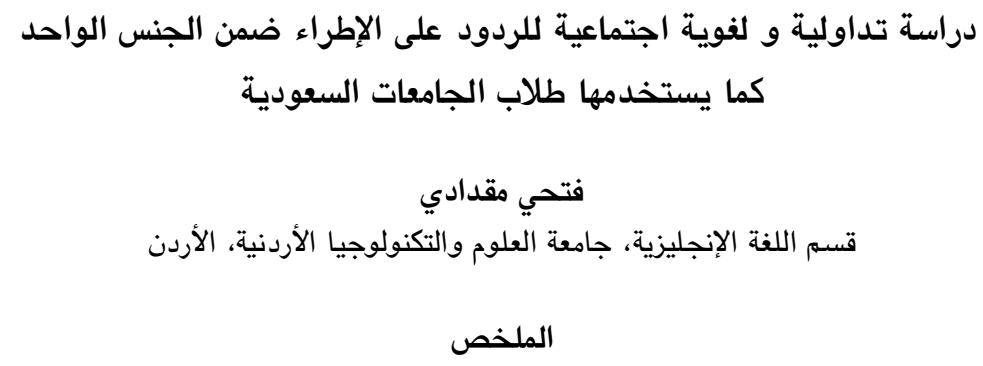

الملخص

تتناول هذه الدراسة الردود على المجاملات التي يستخدمها طلاب الجامعات السعودية ضمن نفس الجنس وتركز على

أنواع الردود المستخدمة، وعلاقتها بجنس المتكلم والمخاطب، والقيم الاجتماعية والثقافية المرتبطة بهذا السلوك اللفوي. تم استخلاص العديد من الردود على المجاملات من طلاب جامعة الملك عبد العزيز باستخدام عدد من صيغ المجاملات الثائعة في اللهجة الحجازية كمحفزات لغوية، وتم تحليل و دراسة الردود التي جمعت من حيث خصائصها الدلالية والتداولية واللغوية الاجتماعية، استناداً لنظريتي ليتش (1983) وبراون وليفنسون (1987) في التأدب اللفوي. ويظهر التحليل أن المتحدثين،

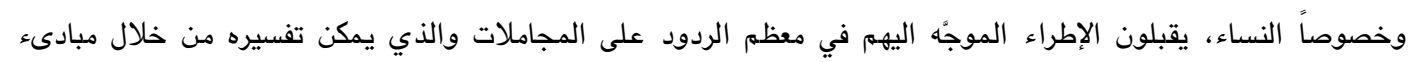
الاستحسان، واللباقة والموافقة حسب نظرية ليتش، إذ يؤكد المتحدثون على التقارب فيما بينهم. ووفقًا لنظرية براون وليفنسون، فإن الردود المتكررة بقبول المجاملات يجعلها إستراتيجيات تأدب إيجابية يقدم فيها المتلقي للإطراء الصداقة والتضامن مع المقدم لهذا الإطراء. ويساهم هذا البحث في تقديم بيانات اضافية لفهم نماذج التأدب المختلفة وتوضيحها واختيارها، فضلاً عن أنه يعمل على إثراء النظرية اللفوية الاجتماعية من خلال دراسة التنوع في استخدام الردود على المجاملات في التفاعلات اللغوية بين المتحدثين من نفس الجنس. الكلمات المفتاحية: صيغ المجاملة ؛ الردود على المجاملات؛ التأدب اللفوي الإيجابي/ السلبي. اللهجة العربية الحجازية. 
A Sociopragmatic Study of Intra-Gender Compliment Responses by Saudi College Students

\section{Endnotes}

${ }^{1}$ Hejazi Arabic is one of three major dialect groups used in Saudi Arabia, the other two being Najdi and Shargi. It is the dialect associated with the western Saudi region, including Mecca, Medina, Jeddah, Rabigh and Yanbu. The dialect is widely understood and is used for government and commercial purposes.

\section{References}

Abdel Hady, Saleem M. N. 2013. Ostensible Invitations in Jordanian Arabic: A Sociopragmatic Study. MA Thesis, Yarmouk University, Jordan.

Armaşu, Veronica-Diana. 2012. Modern Approaches to Politeness Theory. A Cultural Context. Lingua. Language and Culture 11 (1): 9-19

Baba, Junko. 1996. A Study of Interlanguage Pragmatics: Compliment Responses by Learners of Japanese and English as a Second Language. Ph.D. diss., University of Texas at Austin.

Brown, Penelope, and Stephen Levinson. 1987. Politeness: Some Universals in Language Usage. Cambridge: Cambridge University Press.

Chen, Rong. 1993. Responding to compliments: A contrastive Study of Politeness Strategies between American English and Chinese speakers. Journal of Pragmatics 20: 49-75.

Chen, Rong. 2001. Self-politeness: A proposal. Journal of Pragmatics 33 (1): 87-106.

Chen, Rong. 2010. Compliment and Compliment Response Research: A Cross-Cultural Survey. In Pragmatics across Languages and Cultures, edited by Anna Trosborg, 79-101. Berlin: Mouton de Gruyter.

Chen, Rong, and Dafu Yang. 2010. Responding to Compliments in Chinese: Has it changed? Journal of Pragmatics 42: 1951-1963.

Chen, Rong, Lin He, and Chunmei Hu. 2013. Chinese Requests: In comparison to American and Japanese Requests and with Reference to the "East-West divide". Journal of Pragmatics 55: 140-161.

Chen, Shu-hui Eileen. 2003. Compliment Response Strategies in Mandarin Chinese: Politeness Phenomenon Revisited. Concentric: Studies in English Literature and Linguistics 29 (2): 157-184.

Davies, Alan. 1999. An Introduction to Applied Linguistics. Edinburgh: Edinburgh University Press.

De Atkine, Norvell B. 2004. The Arab Mind Revisited. Middle East Quarterly 11 (3): 47-55.

Eelen, Geno. 2001. A Critique of Politeness Theories. Manchester: St. Jerome Publishing.

Farghal, Mohammed. 1993. Arab Fatalism and Translation from Arabic to English. Target 5 (1): 43-53.

Farghal, Mohammed, and Mahmoud Al-Khatib. 2001. Jordanian College Students' Responses to Compliments: A Pilot study. Journal of Pragmatics 33: 1485-1502.

Farghal, Mohammed, and Madeline Haggan. 2006. Compliment Behavior in Bilingual Kuwaiti College Students. International Journal of Bilingual Education and Bilingualism 9 (1): 94-118.

Fraser, Bruce. 1990. Perspectives on Politeness. Journal of Pragmatics 14: 219-236. 
Migdadi

Gu, Yueguo. 1990. Politeness Phenomena in Modern Chinese. Journal of Pragmatics 14: 237-257.

Henderson, Anita. 1996. Compliments, Compliment Responses, and Politeness in an African-American Community. In Sociolinguistic Variation: Data, Theory and Analysis. Selected papers from NWAV 23 at Stanford, 195-208, edited by J. Arnold, R. Blake, B. Davidson, S. Schwenter, and J. Solomon. Stanford, CA: Center for the Study of Language and Information.

Herbert, Robert K. 1986. Say “'Thank you’”-or Something. American Speech 61: 76-88.

Herbert, Robert K. 1989. The Ethnography of English Compliments and Compliment Response: A Contrast and Sketch. In Contrastive Pragmatics, ed. by W. Oleksy, 3-35. Amsterdam: John Benjamins.

Herbert, Robert K. 1990. Sex-Based Differences in Compliment Behavior. Language in Society 19 (2): 201-224.

Herbert, Robert K. 1997. The Sociology of Compliment Work in Polish and English.” In Sociolinguistics, edited by Nikolas Coupland and Adam Joworski, 487-500. London: Macmillan.

Herbert, Robert K., and H. Stephen Straight. 1989. Compliment-rejection vs. Compliment-Avoidance: Listener-Based Vs. Speaker-Based Pragmatic Strategies. Language \& Communication 9: 35-47.

Hill, Beverly, Sachiko Ide, Shako Ikuta, Akiko Kawasaki, and Tsunao Ogino. I986. Universals of Linguistic Politeness: Quantitative Evidence from Japanese and American English. Journal of Pragmatics 10 (3): 347-371.

Holmes, Janet. 1988. Compliments and Compliment Responses in New Zealand English." Anthropological Linguistics 28 (4): 485-508.

Holmes, Janet. 1995. Women, Men and Politeness. London: Longman.

Holmes, Janet. 1998. Women's Talk: The Question of Sociolinguistic Universals. In Language and Gender: A Reader, edited by Jennifer Coates, 461-483. Oxford: Blackwell.

Ide, Sachiko. 1989. Formal Forms and Discernment: Two Neglected Aspects of Linguistic Politeness. Multilingua 8 (2/3): 223-248.

Lakoff, Robin. 1973a. Language and Women's Place. Language in Society 2 (1): 45-80.

Lakoff, Robin.1973b. The logic of Politeness: Or, Minding Your P's and Q's. In Papers from the 9th Regional Meeting of the Chicago Linguistic Society, edited by C. W. Corum, T. Cedric Smith-Stark, and A. Weiser, 292-305. Chicago: Chicago Linguistic Society.

Leech, Geoffrey N. 1983. Principles of Pragmatics. London: Longman.

Lewandowska-Tomaszczyk, Barbara. 1989. Praising and Complimenting. In Contrastive Pragmatics, edited by W. Olesky, 73-100. Amsterdam: John Benjamins.

Lorenzo-Dus, Nuria and Patricia Bou-Franch. 2003. Gender and Politeness: Spanish and British Undergraduates' Perceptions of Appropriate Requests. In Generalde la Mujer, edited by, Lenguajey traducción Género and José Santaemilia, 187-199, Valencia: Universitat de Valencia/ Dirección. Available at https://www.uv.es/ boup/PDF/Requests.pdf

Manes, Joan. 1983. Compliments: A Mirror of Cultural Values. In Sociolinguistics and Language Acquisition, edited by Nessa Wolfson and Elliot Judd, 96-102. Rowley, MA: Newbury House. 
A Sociopragmatic Study of Intra-Gender Compliment Responses by Saudi College Students

Manes, Joan, and Nessa Wolfson. 1981. The Compliment Formula. In Conversational Routines: Explanations in Standardized Communication Situations and Prepatterned Speech, edited by Florian Coulmas, 115-132. The Hague: Mouton.

Migdadi, Fathi. 2003. Complimenting in Jordanian Arabic: A Socio- Pragmatic Analysis. Unpublished $\mathrm{PhD}$ diss., Muncie, IN: Ball State University.

Migdadi, Fathi, Mohammed Badarneh and Kwakib AlMomany. 2010. Divine Will and its Extensions: Communicative Functions of Maašaallah In Colloquial Jordanian Arabic, Communication Monographs 77 (4): 480-499

Morsy, Eman. 1992. Sex Differences in Complimenting Behavior: A Contrastive Analysis between Egyptian Arabic and American English. Unpublished MA thesis, the American University in Cairo.

Nelson, Gayle L.,Waguida El-Bakary, and Mahmoud Al-Batal. 1993. Egyptian and American Compliments: A Cross-Cultural Study. International Journal of Intercultural Relations 17 (3): 293313.

Nelson, Gayle L., Mahmoud Al-Batal, and Erin Echols, 1996. Arabic and English Compliment Responses: Potential for Pragmatic Failure. Applied Linguistics 17 (4): 411-431.

Norrick, Neal. 1993. Conversational Joking: Humor in Everyday Talk. Bloomington: Indiana University Press.

Nydell, Margaret K. 1987. Understanding Arabs: A Guide for Westerners. Yarmouth, ME: Intercultural Press.

Okamoto, Shigeko. 2002. Ideology and Social Meanings: Rethinking the Relationship between Language, Politeness, and Gender. In Gendered practices in language edited by Sara Benor et al. 91-113, Stanford, CA: CSLI Publications.

Othman, Normala. 2001. Pragmatic and Cultural Considerations of Compliment Responses among Malay sian-Malay speakers.” Asiatic 5 (1): 86-103.

Pomerantz, Anita. 1978. Compliment Responses: Notes on the Co-Operation of Multiple Constraints. In Studies in the Organization of Conversational Interaction, ed. by Jim Schenkein, 79-112. London: Academic Press.

Radcliff-Johnson, Mariana and Raheel El-Hilawi. 2016. Ostensible Invitations in Arabic: A Pragmatic Function Analysis. Available at http://semanticsarchive.net/Archive/ ThmNzAyN/radcliffelh ilawi 106.pdf

Ruhi, Şükriye. 2006. Politeness in Compliment Responses: A Perspective from Naturally Occurring Exchanges in Turkish. Pragmatics 16 (1): 43-101.

Spencer-Oatey, Helen. 2000. Rapport Management: A Framework for Analysis. In Culturally Speaking: Managing Rapport Through Talk Across Cultures, edited by Helen Spencer Oatey, 11-46. London: Continuum.

Tannen, Deborah. 1990. You Just Don't Understand: Women and Men in Conversation. New York: William Morrow. 
Tannen, Deborah. 1993. The Relativity of Linguistic Strategies: Rethinking Power and Solidarity in Gender and Dominance. In Gender and Conversational Interaction, edited by Deborah Tannen, $165-$ 189. Oxford: Oxford University Press.

The Linguistic Politeness Research Group (ed.). 2011. Discursive Approaches to Politeness. Berlin: Walter de Gruyter.

Tran, Giao Quynh. 2007. Compliment Response Continuum Hypothesis. The International Journal of Language, Society and Culture 21: 1-22.

Turnbull, William. 2001. An Appraisal of Pragmatic Elicitation Techniques for the Social Psychological Study of Talk: The Case of Request Refusals. Pragmatics 11 (1): 31-61.

Watts, Richard. 2003. Politeness. Cambridge: Cambridge University Press.

Wierzbicka, Anna. 1991. Cross-Cultural Pragmatics: The Semantics of Human Interaction. Berlin: Mouton de Gruyter.

Wolfson, Nessa. 1983. An Empirically Based Analysis of Complimenting in American English. In Sociolinguistics and Language Acquisition, edited by Nessa Wolfson and Elliot Judd, 82-95. Rowley, MA: Newbury House.

Yuan, Li. 2002. Compliments and Compliments Responses in Kunming Chinese. Pragmatics 12 (2): 183-226.

Yuan, Yi. 1998. Sociolinguistics of the Compliment Event in Southeastern Mandarin Chinese. Ph.D. diss., Indiana University. 